\title{
Coronavirus Disease 2019 (COVID-19) and Its Neuroinvasive Capacity: Is It Time for Melatonin?
}

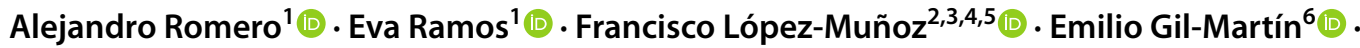 \\ Germaine Escames ${ }^{7,8,9}$ (]) Russel J. Reiter ${ }^{10}$ (])
}

Received: 15 May 2020 / Accepted: 5 August 2020 / Published online: 9 August 2020

(c) Springer Science+Business Media, LLC, part of Springer Nature 2020

\begin{abstract}
The world faces an exceptional new public health concern caused by the severe acute respiratory syndrome coronavirus 2 (SARSCoV-2), subsequently termed the coronavirus disease 2019 (COVID-19) by the World Health Organization (WHO). Although the clinical symptoms mostly have been characterized, the scientific community still doesn't know how SARS-CoV-2 successfully reaches and spreads throughout the central nervous system (CNS) inducing brain damage. The recent detection of SARS-CoV-2 in the cerebrospinal fluid (CSF) and in frontal lobe sections from postmortem examination has confirmed the presence of the virus in neural tissue. This finding reveals a new direction in the search for a neurotherapeutic strategy in the COVID-19 patients with underlying diseases. Here, we discuss the COVID-19 outbreak in a neuroinvasiveness context and suggest the therapeutic use of high doses of melatonin, which may favorably modulate the immune response and neuroinflammation caused by SARS-CoV-2. However, clinical trials elucidating the efficacy of melatonin in the prevention and clinical management in the COVID-19 patients should be actively encouraged.
\end{abstract}

Keywords SARS-CoV-2 $\cdot$ Melatonin $\cdot$ COVID-19 $\cdot$ Central nervous system $\cdot$ Neuroinvasion $\cdot$ Neuroprotection

Abbreviations
ACE2

$\alpha 7 \mathrm{nAChR}$
Angiotensin-converting enzyme 2 receptor

Alpha 7 acetylcholine nicotinic receptor
$\mathrm{Ca}^{2+} / \mathrm{CaMKII} \quad \mathrm{Ca}^{2+} /$ calmodulin-dependent protein

kinase II

$\mathrm{CaM} \quad$ Calmodulin

ERGIC Endoplasmic reticulum-Golgi intermediate compartment
Alejandro Romero

manarome@ucm.es

1 Department of Pharmacology and Toxicology, Faculty of Veterinary Medicine, Complutense University of Madrid, Avda. Puerta de Hierro s/n, 28040 Madrid, Spain

2 Faculty of Health Sciences, University Camilo José Cela, C/ Castillo de Alarcón 49, 28692 Villanueva de la Cañada, Madrid, Spain

3 Neuropsychopharmacology Unit, Hospital 12 de Octubre Research Institute (i+12), Avda. Córdoba, s/n, 28041 Madrid, Spain

4 Portucalense Institute of Neuropsychology and Cognitive and Behavioural Neurosciences (INPP), Portucalense University, R. Dr. António Bernardino de Almeida 541, 4200-072 Porto, Portugal
5 Thematic Network for Cooperative Health Research (RETICS), Addictive Disorders Network, Health Institute Carlos III, MICINN and FEDER, Madrid, Spain

6 Nutrition and Food Science Group, Department of Biochemistry, Genetics and Immunology, Faculty of Biology, University of Vigo, 36310 Vigo, Spain

7 Biomedical Research Center, Health Sciences Technology Park, University of Granada, 18016 Granada, Spain

8 Department of Physiology, University of Granada, 18016 Granada, Spain

9 Centro de Investigación Biomédica en Red de Fragilidad y Envejecimiento Saludable, Instituto de Investigación Biosanitaria CIBERFES, IBS. Granada, Granada Hospital Complex, 18016 Granada, Spain

10 Department of Cellular and Structural Biology, University of Texas Health Science at San Antonio, San Antonio, TX 78229, USA 


\begin{tabular}{|c|c|}
\hline IKK & I-KappaB-alpha kinase complex \\
\hline IL-1 $\beta$ & Interleukin $1 \beta$ \\
\hline IL-6 & Interleukin 6 \\
\hline JAK2 & Janus kinase 2 \\
\hline MT1/MT2 & Melatonin receptor subtypes 1 and 2 \\
\hline $\mathrm{NF}-\kappa \mathrm{B}$ & $\begin{array}{l}\text { Nuclear factor kappa-light-chain-enhanc } \\
\text { of activated B cells }\end{array}$ \\
\hline NLRP3 & NLR pyrin domain containing 3 \\
\hline ROS & Reactive oxygen species \\
\hline SARS-CoV-2 & $\begin{array}{l}\text { Severe acute respiratory syndrome coro- } \\
\text { navirus } 2\end{array}$ \\
\hline STAT3 & $\begin{array}{l}\text { Signal transducers and activators of } \\
\text { transcription }\end{array}$ \\
\hline TLR & Toll like receptor \\
\hline TMPRSS2 & Transmembrane serine protease 2 \\
\hline TNF- $\alpha$ & Tumor necrosis factor- $\alpha$ \\
\hline TNFR & TNF receptor \\
\hline TRADD & TNF receptor-associated death domain \\
\hline TRAF2 & TNF receptor-associated factor- 2 \\
\hline
\end{tabular}

\section{Introduction}

In late December 2019, a number of 27 people with clinical symptoms of dry cough, dyspnea, fever, and bilateral lung infiltrates on imaging with an unknown cause were diagnosed in Wuhan, Hubei Province, China. A few days later, a new virus of great global public health concern was isolated and designated as severe acute respiratory syndrome coronavirus 2 (SARS-CoV-2), later referred to as coronavirus disease 2019 (COVID-19) (Chen et al. 2020a). This new virus was found to be highly contagious and quickly spread globally, leading the World Health Organization (WHO) to officially declare the COVID-19 outbreak a global pandemic on March 11, 2020 (Mahase 2020). As an emerging acute respiratory infectious disease, clinical symptoms are characterized predominantly by fever and dry cough followed by dyspnea, bilateral infiltrates, sputum production, haemoptysis, lymphopenia, shortness of breath, sore throat, and neurological and gastrointestinal manifestations (Huang et al. 2020; Wang et al. 2020a, b). COVID-19 employs cell receptor angiotensin-converting enzyme 2 (ACE2) for host cell entry (Xu et al. 2020a, b; Zhou et al. 2020a, b), which is present in the type II alveolar cells (Zou et al. 2020), enterocytes from ileum and colon (Xiao et al. 2020), liver cholangiocytes (Qi et al. 2020), aqueous humor (Holappa et al. 2015), myocardial cells (Donoghue et al. 2000), proximal tubule kidney cells (Zou et al. 2020), urothelial bladder cells (Zou et al. 2020), epithelial cells of the oral mucosa (Xu et al. 2020a, b), as well as neurons and glia in the brain stem and particular cerebral regions (Xia and Lazartigues 2010). The high expression and wide distribution of ACE2 receptor in human body may sustain the ubiquitous potential infection of COVID-19 and explain its tropism. It is also recognized that COVID-19 could be transmitted via multiple routes, predominantly binding to ACE2 alveolar epithelial cells (Wan et al. 2020; Zhou et al. 2020a, b) or by oral-fecal transmission (Gu et al. 2020), among others. To date, it is accepted that the incubation period of COVID19 is up to 14 days, although it has been suggested that it may be extended up to 24 days, which possibly reflects a double exposure. Furthermore, asymptomatic infection has been additionally reported (Huang et al. 2020; Linton et al. 2020). Interestingly, previous studies showed that the coronavirus also infects the central nervous system (CNS) (Arbour et al. 2000; Lau et al. 2004) since it can spread from the respiratory tract to the CNS, showing neuroinvasive capacities.

There is uncertainty about extra-pulmonary manifestations of COVID-19, including those affecting the CNS. Numerous efforts to implement effective therapeutic strategies are underway. The distressing scenario that the world is experiencing regarding COVID-19 calls for new treatment approaches and, in this respect, we want to emphasize the advantages of melatonin ( $\mathrm{N}$-acetyl-5-methoxytryptamine) as a potential therapeutic agent to ameliorate the CNS damage associated with SARS-CoV-2's disease. Melatonin is not a molecule addressed to diminish the viral load nor target specific enzymes involved in viral replication and transcription, nevertheless it has multiple indirect antiviral actions (Anderson et al. 2015; Elmahallawy et al. 2015; Junaid et al. 2020; Montiel et al. 2015; Tan et al. 2014). In this regard, some recent reviews have suggested the utility of melatonin as adjunctive or even regular therapy for COVID-19 patients who suffer pneumonia, acute lung injury (ALI) and acute respiratory distress syndrome (ARDS) (Tan and Hardeland 2020; Zhang et al. 2020), as well as extra-respiratory complications (Dominguez-Rodriguez et al. 2020; Shneider et al. 2020). Regarding the experimental clinical use of melatonin in the current critical situation, it is important to highlight that melatonin is not only a well-known anti-inflammatory (Carrascal et al. 2018), antioxidative (Rodriguez et al. 2004), and immuneenhancing agent (Carrillo-Vico et al. 2005) but also a molecule with a high safety profile (Seabra et al. 2000). Its small size and amphiphilic nature allow melatonin high cell diffusion capability and it has high permeability through biological compartments, including blood brain barrier (BBB) (Tarocco et al. 2019), reaching cytosolic, mitochondrial, and nuclear compartments (Menendez-Pelaez and 
Reiter 1993; Reiter et al. 2020b). BBB integrity is crucial for the maintenance of CNS, and thus, several neurological disorders debut after deterioration of the BBB (Rosenberg 2012). Melatonin restores BBB homeostasis limiting microvascular hyperpermeability (Alluri et al. 2016; Liu et al. 2017) and therefore making it a promising candidate against neuroinvasion caused by COVID-19. In view of all the above information, this review focuses on characteristics, mechanisms, and implications of CNS involvement caused by SARS-CoV-2 infection, in which we speculate on how the use of the melatonin could become the basis for a possible neurotherapeutic approach.

\section{How Does SARS-CoV-2 Neuroinvasiveness Occur? Melatonin Potential to Respond to COVID-19 Neuropathogenesis}

SARS-CoV-2 shares its clinical symptoms with those described for SARS-CoV and Middle East respiratory syndrome $\mathrm{CoV}$ (MERS-CoV) betacoronaviruses. Previously, it has been reported the presence of SARS-CoV and MERS-CoV particles in the brain of experimental animal models and patients (Ding et al. 2004; Li et al. 2016; Xu et al. 2005). However, regarding SARS-CoV-2, two important questions that arise are as follows: (i) The exact route by which the virus enters the CNS and (ii) whether its presence may be detected in the cerebrospinal fluid (CSF) or postmortem tissue specimens collected from COVID-19 victims. It is known that human coronaviruses can penetrate the CNS through different routes, directly from the external environment affecting the olfactory nerve and olfactory bulb neuroepithelium or using either the lymphatic or the hematogenous route, which represents an excellent opportunity to infect endothelial cells of the BBB (Desforges et al. 2014). It has been recently reported that human ACE2 receptors are the gateway for SARS-CoV-2 and that transmembrane protease serine 2 (TMPRSS2) is essential for the SARS-CoV-2's spike (S) protein activation, which facilitates viral attachment to the surface of target cells (Hoffmann et al. 2020). Consequently, it can be thought that those brain regions with the highest expression of ACE2 receptors could turn out to be more affected by SARS-CoV-2 infection, although the involvement of other receptors or co-receptors is not definitely discarded. In this context, a recent study using mRNA expression levels data provided by the Allen Human Brain Atlas has demonstrated ACE2 in brain regions, such as the olfactory bulb (OB) (Lapina et al. 2020). This may explain the neuropathogenic impact of SARS-CoV-2 on the partial loss of the sense of smell or total anosmia, as a result of nasal inflammation, mucosal edema, and obstruction of airflow into the olfactory cleft. Additionally, the analyses of three databases have shown high expression levels of human ACE2 in several regions of the brain (e.g., substantia nigra) and both neurons and astrocytes, which would help us to understand how SARS-CoV-2 can spread into the brain and cause neurological damage (Chen et al. 2020b) (Fig. 1). Conversely, OB imaging by magnetic resonance was found normal in a COVID-19 patient with anosmia and without intensity signals of nasal congestion in the early phase of the disease (Galougahi et al. 2020); even though, anosmia may persist for a long time. Another essential point for initial viral neuroinvasion is the recent announcement by genome sequencing of the first reported case of SARS-CoV-2 in the CSF (Xiang 2020). Additionally, a recent case study reporting viral particles in endothelial cells and frontal lobe sections obtained at forensic examination confirmed the presence of SARSCoV-2 in neural tissue (Paniz-Mondolfi et al. 2020). After these observations, brain infection is being seriously considered by the scientific community because important pathologies at neurological level are emerging associated with COVID-19 patients; encephalopathy (Filatov et al. 2020; Poyiadji et al. 2020), meningitis/encephalitis (Moriguchi et al. 2020; Ye et al. 2020), Guillain-Barré syndrome (Zhao et al. 2020), cerebrovascular disease (Helms et al. 2020; Wu et al. 2020; Zhai et al. 2020) and epilepsy (Karimi et al. 2020). Moreover, Li and colleagues (Li et al. 2020) have hypothesized that the ability of SARS-CoV-2 targeting the CNS may, at least in part, explain the acute respiratory failure of COVID-19 patients. Conversely, it has also been argued that the brain dysfunction induced by SARS-CoV-2 still lacks strong evidence and, therefore, this relevant question should be further investigated.

Taken together, the abovementioned evidence indicates that counteracting or mitigating the neuroinvasion of SARSCoV-2 emerges as an essential strategy to prevent or treat COVID-19. At this point is where melatonin can act as a protective agent against virus-related diseases (Anderson and Reiter 2020; Elmahallawy et al. 2015; Silvestri and Rossi 2013; Tan et al. 2014) and several pathologies of CNS (Brigo et al. 2016; Farez et al. 2015; Gerber et al. 2005; Ramos et al. 2017) including those affecting BBB (Ramos et al. 2017) (Fig. 1). Regardless, it is possible that melatonin may act inside the neural cells targeted by SARS-CoV-2. Its amphiphilic nature helps it to reach intracellular organelles, binding to mitochondrial and cell cytosol proteins, thus increasing its neural availability (Tan 2010) and therapeutic versatility in at least three different ways. Firstly, melatonin 
Fig. 1 The nasal cavity could be the gateway of SARS-CoV-2 to reach directly the central nervous system through affecting the olfactory nerve and olfactory bulb neuroepithelium. Once in the brain, SARS-CoV-2 would initiate the innate immune responses at early stages of the COVID-19 resulting in neurological disorders. At this point, high doses of melatonin may exert anti-inflammatory effects and act as a buffer against enhanced immunoreactivity, which would reduce the neuropathogenesis of SARS-CoV-2 infection
CNS environment at "cytokine storm syndrome"

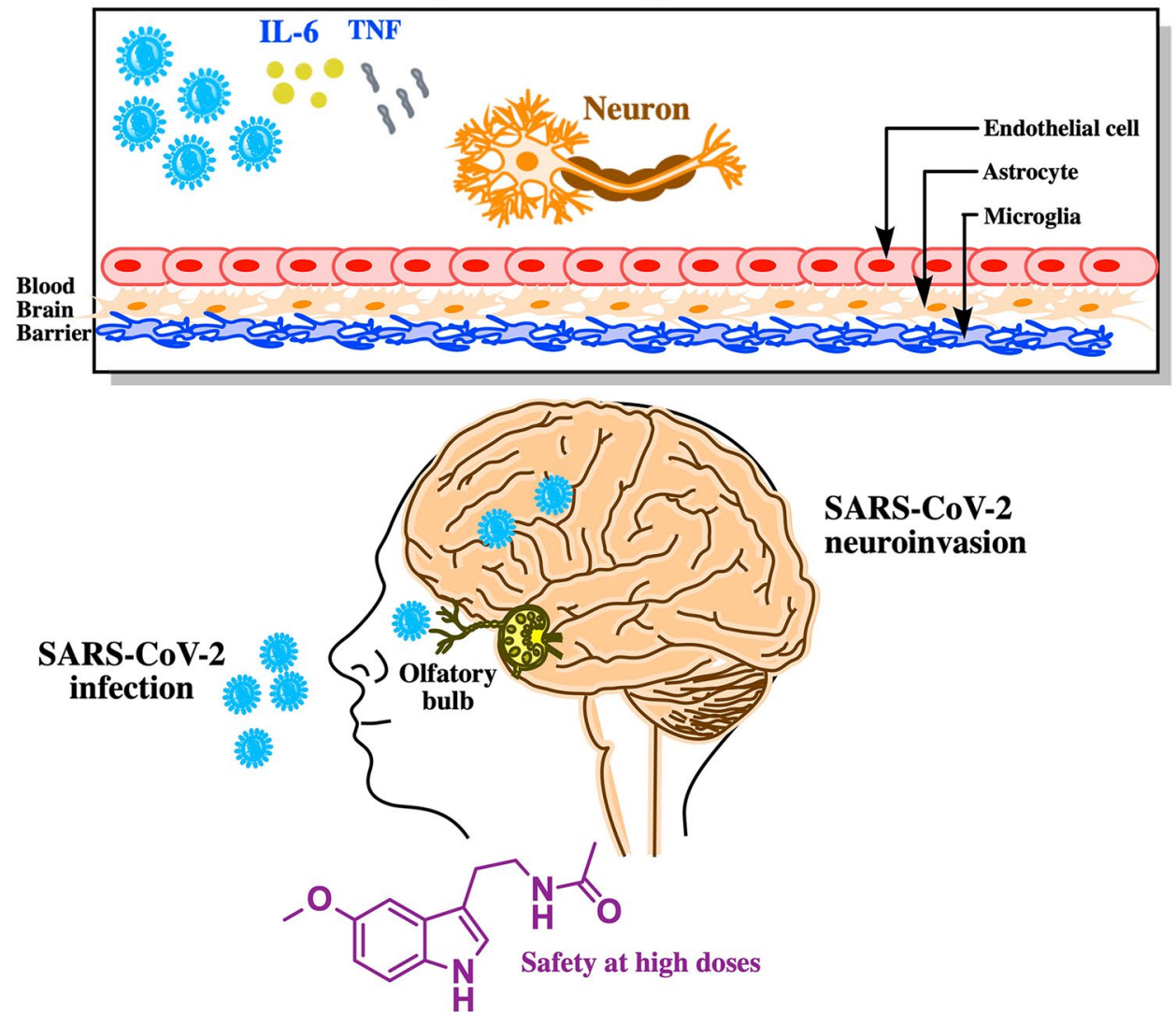

CNS environment after exogenous melatonin administration

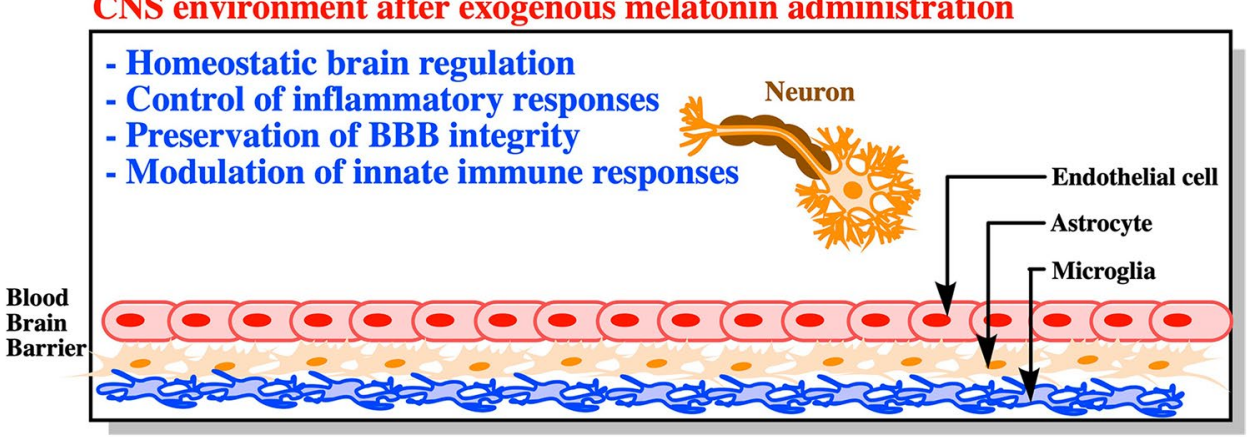

binds to calmodulin $(\mathrm{CaM})$ and may act on the $\mathrm{Ca}^{2+} / \mathrm{calm}$ odulin-dependent protein kinase II $\left(\mathrm{Ca}^{2+} / \mathrm{CaMKII}\right)$ system, thereby regulating the expression of ACE2 (Lambert et al. 2008). Secondly, CaMKII has been found to copurify with proteasomes of the brain (Bingol et al. 2010) and the ubiquitin-proteasome system is involved in the early viral replicative cycle. Interestingly, like a proteasome inhibitor (Vriend and Reiter 2014), melatonin may regulate several events involved in proteostasis, through the $\mathrm{Ca}^{2+} / \mathrm{CaMKII}$ system, which can also influence SARS-CoV-2 infectivity. Thirdly, given its tectonic impact in host cell homeostasis, it is expected that SARS-CoV-2 dysregulates mitochondrial metabolism. In this regard, it is worth noting that many of the actions displayed by melatonin are directed to maintain mitochondrial function (Tan and Reiter 2019). Particularly with respect to neuronal damage, the neuroprotection provided by melatonin has been revealed to be mediated by the high-affinity melatonin receptors hosted in the mitochondria (Tan and Reiter 2019). Therefore, any decrease of melatonin (pineal or mitochondrial) levels may open a way for increasing the viral control of cellular metabolism and thus speeding up the replication of SARS-CoV-2 and severity of many viral infections (Anderson and Reiter 2020).

About $10-15 \%$ of the COVID-19 patients with ARDS and organ failure have been associated with the commonly known as hyperinflammation or "cytokine storm syndrome". The question that arises is; might SARS-CoV-2 infection trigger a cytokine storm in the brain? In light 


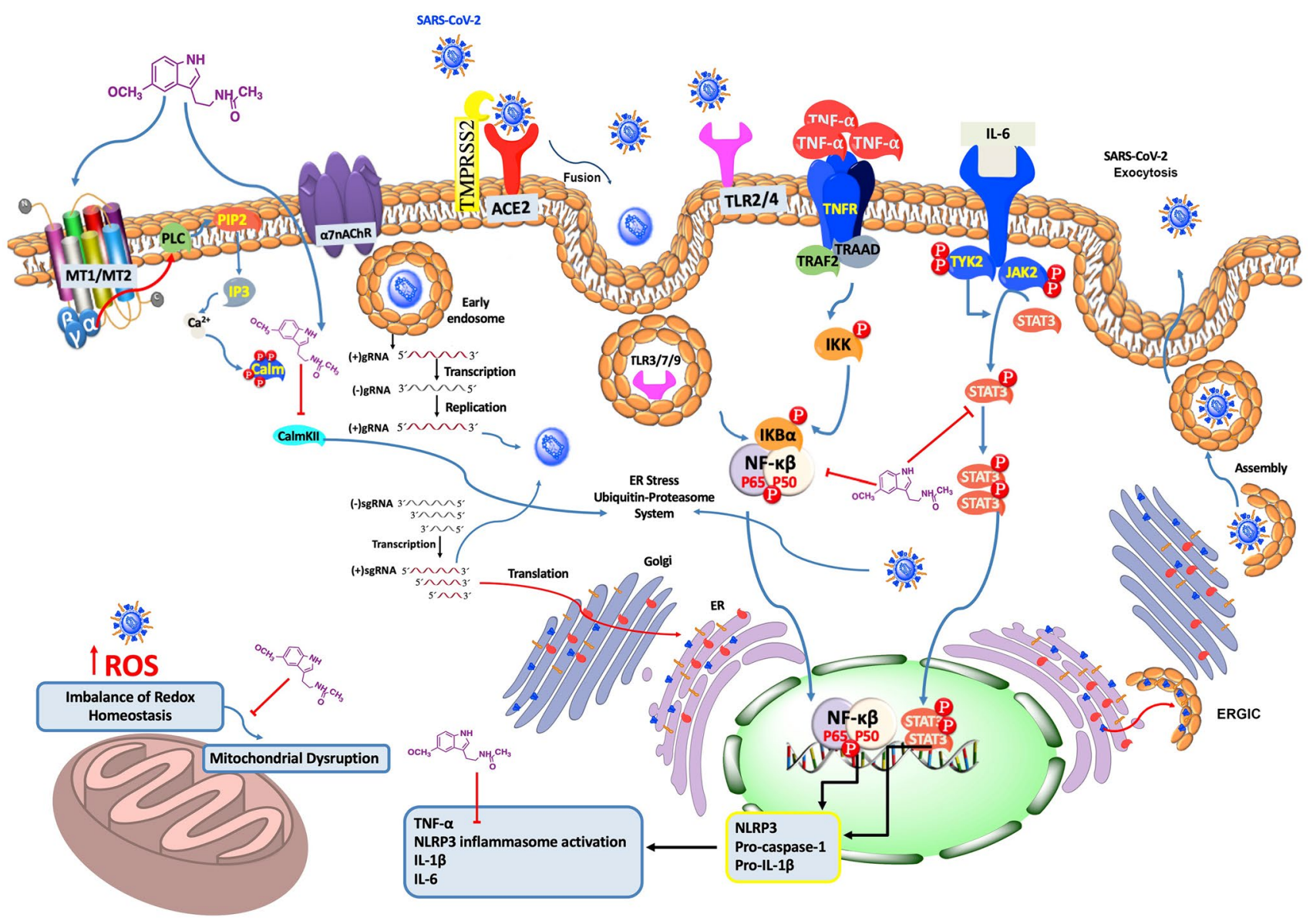

Fig. 2 Hypothetical diagram of the possible targets where melatonin may act against SARS-CoV-2 infection in the CNS. SARS-CoV-2 enters neuronal cells through ACE2, as the receptor binding domain, and TMPRSS2 for spike protein (s protein) priming. Next, SARS$\mathrm{CoV}-2$ nucleocapsid triggers clathrin-mediated endocytosis enhancing cytoplasm release. Subsequently, the single negative strand RNA $[(-)$ gRNA $]$ synthesized from (+)gRNA template is used to replicate more copies of viral RNAs. Afterwards, subgenomic RNAs (sgRNAs) synthesized from the (+)gRNA template encode viral structural and accessory proteins, which are subsequently assembled with newly synthesized viral RNAs in the ER and Golgi, followed by budding into the lumen of the ERGIC to form new virions. Then, virus particles are transported in secretory vesicles to the plasma membrane and released by exocytosis. Furthermore, the entry of SARS-CoV-2 into neuronal cells may dysregulate mitochondrial metabolism increasing ROS and leading to the induction of endoplasmic reticulum stress. In this regard, melatonin's high diffusibility allows it to enter in neuronal cells, it binds to $\mathrm{CaM}$ and may act on the $\mathrm{Ca}^{2+} / \mathrm{CaMKII}$ system, regulating the expression of $\mathrm{ACE} 2$, modulating the linking between endoplasmic reticulum stress and inflammatory response and scavenging ROS. However, in both MT1/MT2 and $\alpha 7 \mathrm{nAChR}$ receptors,

of recent COVID-19-associated case reports describing a rare form of severe brain damage with hemophagocytic lymphohistiocytosis (HLH) (Radmanesh et al. 2020), and a patient with an acute necrotizing hemorrhagic encephalopathy (Poyiadji et al. 2020), it should be considered that COVID-19 infection may induce a "cytokine storm melatonin-mediated signaling may influence in reduced SARS-CoV-2 entry. When SARS-CoV-2 infects the CNS, it triggers the release of pro-inflammatory cytokines. (i) TNF- $\alpha$, which acts by binding to TNFR receptor recruiting TRADD. This protein binds to TRAF2 to phosphorylate and activate the IKK. Then, IKK complex phosphorylates $\mathrm{IKB} \alpha$, resulting in the translocation of NF- $\mathrm{KB}$ to the nucleus, where it targets many coding genes for mediators of inflammatory responses. (ii) IL-6 induces gene activation in response to cytokine receptor stimulation. STAT3 proteins dimerize and translocate to the nucleus. JAK2/STAT3 signaling is a crucial link acting as a pivotal mediator of neuroinflammation. (iii) The binding of SARS-CoV-2 to the TLR (TLR3/7/9) upregulates the pro-inflammatory transcription factor NF- $\mathrm{KB}$ and causes the release of pro-IL- $1 \beta$ which is cleaved by caspase-1, followed by NLRP3 inflammasome activation. Consequently, melatonin may revert these pro-inflammatory effects by inhibiting the JAK2/STAT3 signaling pathway and NF- $\kappa$ B translocation. In addition, as an anti-inflammatory agent, melatonin inhibits the activation of NLRP3 inflammasome. Stimulation (blue colored) or inhibition (red colored) by melatonin and SARS-CoV-2 are also shown. Organelles/structures were not drawn to scale

syndrome" in the brain (Mehta et al. 2020), deserving special consideration and further research. In agreement with the above, it has also been reported that upregulation of pro-inflammatory mediators and a deregulated immune response can be useful predictors of lethality by COVID-19 (Ruan et al. 2020). Therefore, a plethora of 
alterations at interconnected signaling pathways, such as the mammalian target of rapamycin (mTOR) (Zhou et al. 2020a, b), sirtuins (SIRTs) (Anderson and Reiter 2020), NLRP3 inflammasome (Deftereos et al. 2020), Toll Like Receptors (TLRs) (Conti et al. 2020) or single-pass type I transmembrane receptor (Notch) (Rizzo et al. 2020) are key factors that may modulate COVID-19-related cellular and molecular events (Fig. 2). In this context, as an universal regulator targeting a large number of different signaling pathways and physiological processes, melatonin may exerts a significant neuroimmunomodulatory protection against viral infections (Liu et al. 2019; Ma et al. 2018; Shukla et al. 2019; Tiong et al. 2019; Xu et al. 2018). Consequently, the capacity of the indoleamine for counteracting the neuroinvasion by SARS-CoV-2 infection cannot be underestimated, nor neglected and unquestionably it requires further research.

\section{Melatonin Receptors in the Context of CNS Involvement for SARS-CoV-2}

Given the astonishing pleiotropy of melatonin, it may be expected that cellular and molecular mechanisms by which this indoleamine mediates neuroprotection would be complex as well. To a some extent the biological effects of melatonin are mediated through the interaction with two high-affinity $\mathrm{G}$ protein-coupled receptors, MT1 and MT2, which are involved in multiple signaling cascades of cell protection and survival (Liu et al. 2016). Both in the CNS and peripheral organs melatonin receptors are ubiquitously distributed (Ekmekcioglu 2006; Ng et al. 2017). Unfortunately, we must assume our current ignorance of the mechanisms by which MT1 and MT2 may influence melatonin-mediated signaling in the brain of patients afflicted by COVID-19. However, melatonin receptor-mediated protection has been suggested against the lethal viral diseases such as the Venezuelan equine encephalomyelitis (VEE) virus (Valero et al. 2009) as well as in the improvement of antioxidative defense system against respiratory syncytial virus (RSV) (Huang et al. 2010).

It has been reported that $1 / 3$ patients with confirmed COVID-19 present acute cerebrovascular disease and epilepsy, among other neurological symptoms (Jin et al. 2020; Mao et al. 2020). It is also known that COVID-19 patients might develop a "cytokine storm syndrome" due to an exacerbated level of pro-inflammatory biomarkers which contribute to significantly increase the risk of ischemic stroke. In this regard, SARS-CoV-2 may enter the CNS via the haematogenous diffusion and infect the endothelial cells of the BBB. It is important to note that melatonin may elicit part of its neuroprotective effect through melatonin receptors, and in this context MT2 upregulation would not only preserve BBB integrity but also attenuate the activation of astrocytes and microglia (Lee et al. 2010). Indeed, downregulation of the hippocampal MT2 receptor has been shown to confer protection against seizures and also exhibited the anticonvulsant activity of melatonin (Stewart and Leung 2005). Additionally, T lymphocytes seem to be more vulnerable against SARS-CoV-2 infection through S protein and CD147 (Wang et al. 2020a, b), an extracellular matrix metalloproteinase that induces the pro-inflammatory cytokine cyclophilin A, secreted by monocytes/macrophages and endothelial cells. T lymphocytes express both melatonin receptors, MT1 and MT2 (Pozo et al. 2004; Slominski et al. 2012), and hence, in the infected $\mathrm{T}$ cells melatonin may regulate the immunostimulatory activity mediated by MT1 and MT2 and block cyclophilin A/CD147 signaling pathway (Su et al. 2016). For these reasons, in the search for new pharmacological strategies against COVID-19, we focused our attention on the exogenous supplementation with melatonin to preserve the immune response and counteract the neuroinflammation through its widely distributed receptors in the CNS and most of the immune cells.

\section{Understanding of COVID-19's Long-Term Impact on the CNS and the Influence of Melatonin as a Preventive Agent}

All countries are suffering the scourge of COVID-19. Unfortunately, science is still learning the natural history and pathogenicity of this emerging coronavirus as well as its immediate and devastating effects on human health. We should ask ourselves, what will be the long-term consequences of COVID-19? Lippi and co-workers (Lippi et al. 2020) have proposed the possibility that months or years after infection several tissues, including the brain, patients may suffer an accelerated aging, which could manifest in neurodegenerative disorders such as Parkinson disease. Something that seems epidemiologically proven is that the most susceptible people to SARS-CoV-2 infection are the middle-aged and elderly. Based on this clinical evidence, we hypothesize that, at least partially, the progressive melatonin decline with age may account for the apparent increased COVID19 sensitivity over life-span and specially in the elderly. As a consequence of aging, the pineal gland accumulates calcium deposits and both serum and CSF melatonin release decreases (Reiter et al. 1981, 2014), which is being increasingly related with numerous dysfunctions and pathophysiological changes (Karasek 2004). The involvement of melatonin in the context of neurodegeneration is promising since it has been well documented to counteract most of the physiopathological events that trigger neurodegenerative disorders (Ramos et al. 2020). Interestingly, a certain relationship 
between nicotinic acetylcholine receptors (nAChRs) and infectivity by SARS-CoV-2 is suspected. However, this raises the controversy about whether it is a facilitating effect because nicotine would promote SARS-CoV-2 cell penetration through nAChRs upregulation (nAChRs) (Kabbani and Olds 2020) or the opposite by the low prevalence of smokers among COVID-19 people in China (Guan et al. 2020) or the hypothesized competition of nicotine and SARS-CoV-2 for binding nAChR (Changeux et al. 2020). Thereby, a putative role of nAChRs in the modulation of ACE2 has been suggested at cardiovascular level (Oakes et al. 2018) and presently it should be considered a possible interplay between both ACE2 and overexpressed nAChRs in the context of the SARS-CoV-2 neurotropism and neuroinfection. At this point, melatonin becomes relevant by the modulation of neuroinflammation (Niranjan et al. 2012) and oxidative stress (Parada et al. 2014) through the alpha 7 acetylcholine nicotinic receptor $(\alpha 7 \mathrm{nAChR})$, which oligomers are among the most frequent in the brain (Gotti and Clementi 2004) and mediate many of the beneficial actions of the indoleamine including mitochondrial regulation. It is also noteworthy that the COVID-19 may impact on the neurotransmission process. Using a multiexperiment matrix Nataf (Nataf 2020) has shown a significant co-expression of ACE2 and Dopa Decarboxylase (DDC), which may explain that any SARS-CoV-2-induced downregulation of ACE2 expression, previously reported for SARS-CoV (Kuba et al. 2005), might disrupt the dopamine and serotonin synthesis pathway. Subsequently, the depletion of these neurotransmitters in blood and brain may reduce the serotonin-dependent melatonin availability. However, this hypothesis should be corroborated and correlated in COVID-19 patients affected by generalized anxiety disorder and depressive symptoms (Huang and Zhao 2020).

\section{Melatonin Supplementation Against SARS-CoV-2 Neurotropism: Dosage and Safety}

To our knowledge, some clinical trials of melatonin in COVID-19 that are currently underway have recently been authorized. Among them, the trial EudraCT: 2020001808-42 has been just approved by the Spanish Agency of Medicines and Medical Devices (AEMPS 2020), trying to identify the doses of melatonin that can be effective in treating the disease. The study is a phase II, single-center, double-blind, randomized placebo-controlled trial, with the objective to address the efficacy and safety of intravenous melatonin administration in ICU patients suffering from COVID-19. Likewise, the State University of New York at Buffalo is sponsoring "Safety and Efficacy of Melatonin in Outpatients Infected With COVID-19 (COVID-19)", a pilot randomized, double-blind, placebo-controlled clinical trial to evaluate the safety and efficacy of melatonin in outpatient adult patients suspected to be afflicted with COVID19. Another example of an interventional clinical trial is provided by Brazil, one of the countries most dramatically hit by the pandemic. The Associação Fundo de Incentivo à Pesquisa is carrying out the trial "Adjuvant Therapeutic Effects of Melatonin Agonist on Hospitalized Patients With Confirmed or Suspected COVID-19" to reduce the lung burden of COVID-19 testing the efficacy of melatonin agonist ramelteon in hospitalized patients.

Nevertheless, determining the safety and the precise doses of this molecule to prescribe are challenges still to be fulfilled. When orally administered, melatonin has a low and variable bioavailability ranging into 3-33\% (Andersen et al. 2016c; Di et al. 1997; Harpsoe et al. 2015). Moreover, brain is the organ where melatonin reaches lower concentration after its administration, which could justify the use of higher doses to counteract the neuroinvasive potential of SARS-CoV-2 (Andersen et al. 2016b). In this regard, a new melatonin galenic formulation with a higher bioavailability and faster absorption through the CNS would be required, such as intravenous (IV) (Peschechera and Veronesi 2020) or intranasal administration (García-García et al. 2016; Zetner et al. 2016).

Even though there are not sufficient short- or long-term studies with exogenous melatonin focused on clarifying clinical safety (Seabra et al. 2000), a significant number of studies and clinical trials indicated that the melatonin is safe, even at doses 100 times higher than physiological concentrations (Andersen et al. 2016a, 2016b; Brzezinski 1997; Nickkholgh et al. 2011; Seabra et al. 2000). Then, what are the recommended melatonin dosing regimens in COVID-19 patients? The answer would depend on the administration route and formulation. Reiter et al. (Reiter et al. 2020a) have recently proposed a dose of $40 \mathrm{mg}$ /day orally to control the spread of the disease. In this regard, we hypothesized for COVID-19 patients in hyperinflammation phase an oral dose of $100 \mathrm{mg} /$ day or that at least $1 \mathrm{mg} / \mathrm{kg}$ b.w would be required to establish whether melatonin inhibits the neuro-impact of SARS-CoV-2, especially among patients with severe neurological pathologies. However, the authors are not unaware of some potential risks reported for low/medium doses of this indoleamine, as has been the case in a few patients with coronary artery disease receiving $5 \mathrm{mg}$ of melatonin before bedtime for a few weeks or months, who developed nonoptimal arterial hypertension side effects (Rechciński et al. 2010), perhaps due to hormone interference with antihypertensive pharmacotherapy (Lusardi et al. 2000). These potential risks must be carefully warned considering that individuals affected by previous cardiovascular comorbidity often develop particularly acute and life-threatening forms of COVID-19 (Nishiga et al. 2020). Also, worth mentioning 
in order to schedule melatonin with null risk is to attend its possible synergy with other hypnotic-sedative pharmacopoeia, as short-term potentiation has been described for melatonin (2 mg) and zolpidem co-administration (Otmani et al. 2008) or other Z-drugs (Frisher et al. 2016). However, the reported adverse side effects of oral melatonin have been minor, sporadic of easy clinical management (Foley and Steel 2019). Melatonin co-administration with other drugs is also an attractive strategy to improve the management of patients with COVID-19 and reducing the possible drug side effects. Accordingly, the potential of melatonin as an adjuvant treatment (Zhang et al. 2020), as well as its combination with mercaptopurine (Zhou et al. 2020a, b) and other therapy protocols (El-Missiry et al. 2020) had been suggested as a feasible therapy against SARS-CoV-2 .

Since the effective vaccine and antiviral drugs are still unavailable, it is critically important to look for an alternative strategy for COVID-19 treatment. To this aim, melatonin is a serious candidate to consider because it shows a low toxicity risk and the pharmacological efficacy needed for the preventive treatment of COVID-19 infection. Moreover, neurophysiological actions from which the clinical management and outcome of COVID-19 patients could benefit. It is time, therefore, to translate the therapeutic capacities of melatonin for the improvement of clinical practice and protection of public health in the current COVID-19 outbreak.

\section{Concluding Remarks}

The current SARS-CoV-2 pandemic has stressed the public health systems until unprecedented limits. The socio-economic consequences are expected to be terrible worldwide and, most important, a health threat has spread across the planet. Faced with this panorama, people are reacting with panic to SARS-CoV-2 infection since several issues have to be solving. (i) The mechanisms associated with the infectiousness of SARS-CoV-2 are not clear and their elucidation is urgently needed. (ii) SARS-CoV-2 causes different symptoms in different people and a biological explanation is lacking. (iii) Clinicians are still unsure whether people infected with COVID-19 can be reinfected. (iv) The lack of effective vaccines and specific antiviral drugs targeted at SARS-CoV-2 makes COVID-19 difficult for treating and controlling the pandemic. And (v) what will the long-term health consequences of affected COVID-19 patients be? Given the current scenario of such an uncertain future facing us at the present time, we emphasize that further investigation in the treatment with melatonin is urgently required, as well as that clinical trials are strongly needed for the best understanding of the impact of its administration in patients affected by COVID-19.
Acknowledgements A.R. thanks UCJC (NEWTHERMEL) for its continued support.

Author Contributions Conceptualization, AR; Writing Original Draft Preparation, AR. Writing-Review \& Editing, AR, ER, EG-M, FL-M, GE and RJR; Supervision, AR, EG-M and RJR; Funding Acquisition, AR. All authors listed above have approved the final version of the manuscript.

\section{Compliance with Ethical Standards}

Conflict of interest The authors declare no conflict of interest.

\section{References}

Alluri H, Wilson RL, Anasooya Shaji C, Wiggins-Dohlvik K, Patel S, Liu Y, Peng X, Beeram MR, Davis ML, Huang JH, Tharakan B (2016) Melatonin preserves blood-brain barrier integrity and permeability via matrix metalloproteinase-9 inhibition. PLoS ONE 11:e0154427. https://doi.org/10.1371/journal.pone.0154427

Andersen LP, Gogenur I, Rosenberg J, Reiter RJ (2016a) The safety of melatonin in humans. Clin Drug Investig 36:169-175. https ://doi.org/10.1007/s40261-015-0368-5

Andersen LP, Werner MU, Rosenkilde MM, Fenger AQ, Petersen MC, Rosenberg J, Gogenur I (2016b) Pharmacokinetics of high-dose intravenous melatonin in humans. J Clin Pharmacol 56:324-329. https://doi.org/10.1002/jcph.592

Andersen LP, Werner MU, Rosenkilde MM, Harpsoe NG, Fuglsang H, Rosenberg J, Gogenur I (2016c) Pharmacokinetics of oral and intravenous melatonin in healthy volunteers. BMC Pharmacol Toxicol 17:8. https://doi.org/10.1186/s40360-016-0052-2

Anderson G, Maes M, Markus RP, Rodriguez M (2015) Ebola virus: melatonin as a readily available treatment option. J Med Virol 87:537-543. https://doi.org/10.1002/jmv.24130

Anderson G, Reiter RJ (2020) Melatonin: roles in influenza, COVID19, and other viral infections. Rev Med Virol 30:e2109. https:// doi.org/10.1002/rmv.2109

Arbour N, Day R, Newcombe J, Talbot PJ (2000) Neuroinvasion by human respiratory coronaviruses. J Virol 74:8913-8921. https ://doi.org/10.1128/jvi.74.19.8913-8921.2000

Bingol B, Wang CF, Arnott D, Cheng D, Peng J, Sheng M (2010) Autophosphorylated CaMKIIalpha acts as a scaffold to recruit proteasomes to dendritic spines. Cell 140:567-578. https://doi. org/10.1016/j.cell.2010.01.024

Brigo F, Igwe SC, Del Felice A (2016) Melatonin as add-on treatment for epilepsy. Cochrane Database Syst Rev. https://doi. org/10.1002/14651858.CD006967.pub4

Brzezinski A (1997) Melatonin in humans. N Engl J Med 336:186-195. https://doi.org/10.1056/NEJM199701163360306

Carrascal L, Nunez-Abades P, Ayala A, Cano M (2018) Role of melatonin in the inflammatory process and its therapeutic potential. Curr Pharm Des 24:1563-1588. https://doi.org/10.2174/13816 12824666180426112832

Carrillo-Vico A, Guerrero JM, Lardone PJ, Reiter RJ (2005) A review of the multiple actions of melatonin on the immune system. Endocrine 27:189-200. https://doi.org/10.1385/ENDO:27:2:189

Changeux JP, Amoura Z, Rey F, Miyara M (2020) A nicotinic hypothesis for Covid-19 with preventive and therapeutic implications. Qeios. https://doi.org/10.32388/FXGQSB

Chen N, Zhou M, Dong X, Qu J, Gong F, Han Y, Qiu Y, Wang J, Liu Y, Wei Y, Xia J, Yu T, Zhang X, Zhang L (2020a) Epidemiological and clinical characteristics of 99 cases of 2019 
novel coronavirus pneumonia in Wuhan, China: a descriptive study. Lancet 395:507-513. https://doi.org/10.1016/S0140 $-6736(20) 30211-7$

Chen R, Wang K, Yu J, Chen Z, Wen C, Xu Z (2020b) The spatial and cell-type distribution of SARS-CoV-2 receptor ACE2 in human and mouse brain. bioRxiv. https://doi. org/10.1101/2020.04.07.030650

Conti P, Ronconi G, Caraffa A, Gallenga CE, Ross R, Frydas I, Kritas SK (2020) Induction of pro-inflammatory cytokines (IL-1 and IL-6) and lung inflammation by Coronavirus-19 (COVI-19 or SARS-CoV-2): anti-inflammatory strategies. J Biol Regul Homeost Agents 34:1. https://doi.org/10.23812/CONTI-E

Deftereos SG, Siasos G, Giannopoulos G et al (2020) The Greek study in the effects of colchicine in COvid-19 complications prevention (GRECCO-19 study): rationale and study design. Hell J Cardiol 61:42-45. https://doi.org/10.1016/j.hjc.2020.03.002

Desforges M, Le Coupanec A, Stodola JK, Meessen-Pinard M, Talbot PJ (2014) Human coronaviruses: viral and cellular factors involved in neuroinvasiveness and neuropathogenesis. Virus Res 194:145-158. https://doi.org/10.1016/j.virusres.2014.09.011

Di WL, Kadva A, Johnston A, Silman R (1997) Variable bioavailability of oral melatonin. N Engl J Med 336:1028-1029. https://doi. org/10.1056/NEJM199704033361418

Ding Y, He L, Zhang Q et al (2004) Organ distribution of severe acute respiratory syndrome (SARS) associated coronavirus (SARS$\mathrm{CoV}$ ) in SARS patients: implications for pathogenesis and virus transmission pathways. J Pathol 203:622-630. https://doi. org/10.1002/path. 1560

Dominguez-Rodriguez A, Abreu-Gonzalez P, Marik PE, Reiter RJ (2020) Melatonin, cardiovascular disease and COVID-19: a potential therapeutic strategy? Melatonin Res 3:318-321. https ://doi.org/10.32794/mr11250065

Donoghue M, Hsieh F, Baronas E, Godbout K, Gosselin M, Stagliano N, Donovan M, Woolf B, Robison K, Jeyaseelan R, Breitbart RE, Acton S (2000) A novel angiotensin-converting enzyme-related carboxypeptidase (ACE2) converts angiotensin I to angiotensin 1-9. Circ Res 87:E1-9. https://doi.org/10.1161/01.res.87.5.e1

Ekmekcioglu C (2006) Melatonin receptors in humans: biological role and clinical relevance. Biomed Pharmacother 60:97-108. https ://doi.org/10.1016/j.biopha.2006.01.002

Elmahallawy EK, Luque JO, Aloweidi AS, Gutiérrez-Fernández J, Sampedro-Martínez A, Rodriguez-Granger J, Kaki A, Agil A (2015) Potential relevance of melatonin against some infectious agents: a review and assessment of recent research. Curr Med Chem 22:3848-3861. https://doi.org/10.2174/092986732266615 0827093730

El-Missiry MA, El-Missiry ZMA, Othman AI (2020) Melatonin is a potential adjuvant to improve clinical outcomes in individuals with obesity and diabetes with coexistence of Covid-19. Eur J Pharmacol 882:173329. https://doi.org/10.1016/j.ejpha r.2020.173329

Farez MF, Mascanfroni ID, Méndez-Huergo SP, Yeste A, Murugaiyan G, Garo LP, Balbuena Aguirre ME, Patel B, Ysrraelit MC, Zhu C, Kuchroo VK, Rabinovich GA, Quintana FJ, Correale J (2015) Melatonin contributes to the seasonality of multiple sclerosis relapses. Cell 162:1338-1352. https://doi.org/10.1016/j. cell.2015.08.025

Filatov A, Sharma P, Hindi F, Espinosa PS (2020) Neurological complications of coronavirus disease (COVID-19): encephalopathy. Cureus 12:e7352. https://doi.org/10.7759/cureus.7352

Foley HM, Steel AE (2019) Adverse events associated with oral administration of melatonin: a critical systematic review of clinical evidence. Compl Ther Med 42:65-81. https://doi.org/10.1016/j. ctim.2018.11.003

Frisher M, Gibbons N, Bashford J, Chapman S, Weich S (2016) Melatonin, hypnotics and their association with fracture: a matched cohort study. Age Ageing 45(6):801-806. https://doi. org/10.1093/ageing/afw123

Galougahi MK, Ghorbani J, Bakhshayeshkaram M, Naeini AS, Haseli S (2020) Olfactory bulb magnetic resonance imaging in SARSCoV-2-induced anosmia: the first report. Acad Radiol 27:892893. https://doi.org/10.1016/j.acra.2020.04.002

García-García P, López-Muñoz F, Álamo C (2016) New galenic formulations of melatonin. In: López-Muñoz F, Srinivasan V, de Berardis D, Álamo C, Kato TA (eds) Melatonin, neuroprotective agents and antidepressant therapy. Springer India, New Delhi, pp 193-202

Gerber J, Lotz M, Ebert S, Kiel S, Huether G, Kuhnt U, Nau R (2005) Melatonin is neuroprotective in experimental Streptococcus pneumoniae meningitis. J Infect Dis 191:783-790. https://doi. org/10.1086/427816

Gotti C, Clementi F (2004) Neuronal nicotinic receptors: from structure to pathology. Prog Neurobiol 74:363-396. https://doi. org/10.1016/j.pneurobio.2004.09.006

Gu J, Han B, Wang J (2020) COVID-19: gastrointestinal manifestations and potential fecal-oral transmission. Gastroenterology 158:1518-1519. https://doi.org/10.1053/j.gastro.2020.02.054

Guan WJ, Ni ZY, Hu Y, Liang WH, Ou CQ, He JX, Liu L, Shan H, Lei CL, Hui DSC, Du B, Li LJ, Zeng G, Yuen KY, Chen RC, Tang CL, Wang T, Chen PY, Xiang J, Li SY, Wang JL, Liang ZJ, Peng YX, Wei L, Liu Y, Hu YH, Peng P, Wang JM, Liu JY, Chen Z, Li G, Zheng ZJ, Qiu SQ, Luo J, Ye CJ, Zhu SY, Zhong NS, China Medical Treatment Expert Group for Covid-19 (2020) Clinical characteristics of coronavirus disease 2019 in China. N Engl J Med 382:1708-1720. https://doi.org/10.1056/NEJMoa2002032

Harpsoe NG, Andersen LP, Gogenur I, Rosenberg J (2015) Clinical pharmacokinetics of melatonin: a systematic review. Eur J Clin Pharmacol 71:901-909. https://doi.org/10.1007/s0022 8-015-1873-4

Helms J, Kremer S, Merdji H, Clere-Jehl R, Schenck M, Kummerlen C, Collange O, Boulay C, Fafi-Kremer S, Ohana M, Anheim M, Meziani F (2020) Neurologic features in severe SARS-CoV-2 infection. N Engl J Med 382:2268-2270. https://doi.org/10.1056/ NEJMc2008597

Hoffmann M, Kleine-Weber H, Schroeder S, Krüger N, Herrler T, Erichsen S, Schiergens TS, Herrler G, Wu NH, Nitsche A, Müller MA, Drosten C, Pöhlmann S (2020) SARS-CoV-2 cell entry depends on ACE2 and TMPRSS2 and is blocked by a clinically proven protease inhibitor. Cell 181:271-280. https://doi. org/10.1016/j.cell.2020.02.052

Holappa M, Valjakka J, Vaajanen A (2015) Angiotensin(1-7) and ACE2, "The Hot Spots" of renin-angiotensin system, detected in the human aqueous humor. Open Ophthalmol J 9:28-32. https ://doi.org/10.2174/1874364101509010028

Huang C, Wang Y, Li X, Ren L, Zhao J, Hu Y, Zhang L, Fan G, Xu J, Gu X, Cheng Z, Yu T, Xia J, Wei Y, Wu W, Xie X, Yin W, Li H, Liu M, Xiao Y, Gao H, Guo L, Xie J, Wang G, Jiang R, Gao Z, Jin Q, Wang J, Cao B (2020) Clinical features of patients infected with 2019 novel coronavirus in Wuhan, China. Lancet 395:497-506. https://doi.org/10.1016/S0140-6736(20)30183-5

Huang SH, Cao XJ, Liu W, Shi XY, Wei W (2010) Inhibitory effect of melatonin on lung oxidative stress induced by respiratory syncytial virus infection in mice. J Pineal Res 48:109-116. https:// doi.org/10.1111/j.1600-079X.2009.00733.x

Huang Y, Zhao N (2020) Generalized anxiety disorder, depressive symptoms and sleep quality during COVID-19 outbreak in China: a web-based cross-sectional survey. Psychiatry Res 288:112954. https://doi.org/10.1016/j.psychres.2020.112954

Jin H, Hong C, Chen S, Zhou Y, Wang Y, Mao L, Li Y, He Q, Li M, Su Y, Wang D, Wang L, Hu B (2020) Consensus for prevention and management of coronavirus disease 2019 (COVID-19) 
for neurologists. Stroke Vasc Neurol 5:146-151. https://doi. org/10.1136/svn-2020-000382

Junaid A, Tang H, Reeuwijk AV, Abouleila Y, Wuelfroth P, Duinen VV, Stam W, Zonneveld AJV, Hankemeier T, Mashaghi A (2020) Ebola hemorrhagic shock syndrome-on-a-chip. iScience 23:100765. https://doi.org/10.1016/j.isci.2019.100765

Kabbani N, Olds JL (2020) Does COVID19 infect the brain? If so, smokers might be at a higher risk. Mol Pharmacol 97:351-353. https://doi.org/10.1124/molpharm.120.000014

Karasek M (2004) Melatonin, human aging, and age-related diseases. Exp Gerontol 39:1723-1729. https://doi.org/10.1016/j.exger .2004 .04 .012

Karimi N, Sharifi Razavi A, Rouhani N (2020) Frequent convulsive seizures in an adult patient with COVID-19: a case report iran red crescent. Med J 22:e102828. https://doi.org/10.5812/ircmj .102828

Kuba K, Imai Y, Rao S, Gao H, Guo F, Guan B, Huan Y, Yang P, Zhang Y, Deng W, Bao L, Zhang B, Liu G, Wang Z, Chappell M, Liu Y, Zheng D, Leibbrandt A, Wada T, Slutsky AS, Liu D, Qin C, Jiang C, Penninger JM (2005) A crucial role of angiotensin converting enzyme 2 (ACE2) in SARS coronavirus-induced lung injury. Nat Med 11:875-879. https://doi.org/10.1038/nm1267

Lambert DW, Clarke NE, Hooper NM, Turner AJ (2008) Calmodulin interacts with angiotensin-converting enzyme-2 (ACE2) and inhibits shedding of its ectodomain. FEBS Lett 582:385-390. https://doi.org/10.1016/j.febslet.2007.11.085

Lapina C, Rodic M, Peschanski D, Mesmoudi S (2020) The potential genetic network of human brain SARS-CoV-2 infection. bioRxiv. https://doi.org/10.1101/2020.04.06.027318

Lau KK, Yu WC, Chu CM, Lau ST, Sheng B, Yuen KY (2004) Possible central nervous system infection by SARS coronavirus. Emerg Infect Dis 10:342-344. https://doi.org/10.3201/eid1002.030638

Lee CH, Yoo KY, Choi JH, Park OK, Hwang IK, Kwon YG, Kim YM, Won MH (2010) Melatonin's protective action against ischemic neuronal damage is associated with up-regulation of the MT2 melatonin receptor. J Neurosci Res 88:2630-2640. https://doi. org/10.1002/jnr.22430

Li K, Wohlford-Lenane C, Perlman S, Zhao J, Jewell AK, Reznikov LR, Gibson-Corley KN, Meyerholz DK, McCray PB Jr (2016) Middle East Respiratory Syndrome Coronavirus causes multiple organ damage and lethal disease in mice transgenic for human dipeptidyl peptidase 4. J Infect Dis 213:712-722. https://doi. org/10.1093/infdis/jiv499

Li YC, Bai WZ, Hashikawa T (2020) The neuroinvasive potential of SARS-CoV2 may play a role in the respiratory failure of COVID19 patients. J Med Virol 92:552-555. https://doi.org/10.1002/ jmv. 25728

Linton NM, Kobayashi T, Yang Y, Hayashi K, Akhmetzhanov AR, Jung SM, Yuan B, Kinoshita R, Nishiura H (2020) Incubation period and other epidemiological characteristics of 2019 novel coronavirus infections with right truncation: a statistical analysis of publicly available case data. J Clin Med 9:538. https://doi. org/10.3390/jcm 9020538

Lippi A, Domingues R, Setz C, Outeiro TF, Krisko A (2020) SARSCoV-2: at the crossroad between aging and neurodegeneration. Mov Disord 35:716-720. https://doi.org/10.1002/mds.28084

Liu J, Clough SJ, Hutchinson AJ, Adamah-Biassi EB, Popovska-Gorevski M, Dubocovich ML (2016) MT1 and MT2 melatonin receptors: a therapeutic perspective. Annu Rev Pharmacol Toxicol 56:361-383. https://doi.org/10.1146/annurev-pharmtox-01081 4-124742

Liu L, Chen H, Jin J, Tang Z, Yin P, Zhong D, Li G (2019) Melatonin ameliorates cerebral ischemia/reperfusion injury through SIRT3 activation. Life Sci 239:117036. https://doi.org/10.1016/j. lfs.2019.117036
Liu WC, Wang X, Zhang X, Chen X, Jin X (2017) Melatonin supplementation, a strategy to prevent neurological diseases through maintaining integrity of blood brain barrier in old people. Front Aging Neurosci 9:165. https://doi.org/10.3389/fnagi.2017.00165

Lusardi P, Piazza E, Fogari R (2000) Cardiovascular effects of melatonin in hypertensive patients well controlled by nifedipine: a 24-hour study. Br J Clin Pharmacol 49:423-427. https://doi.org /10.1046/j.1365-2125.2000.00195.x

Ma S, Chen J, Feng J, Zhang R, Fan M, Han D, Li X, Li C, Ren J, Wang Y, Cao F (2018) Melatonin ameliorates the progression of atherosclerosis via mitophagy activation and NLRP3 inflammasome inhibition. Oxid Med Cell Longev 2018:9286458. https:// doi.org/10.1155/2018/9286458

Mahase E (2020) Covid-19: WHO declares pandemic because of "alarming levels" of spread, severity, and inaction. BMJ 368:m1036. https://doi.org/10.1136/bmj.m1036

Mao L, Jin H, Wang M, Hu Y, Chen S, He Q, Chang J, Hong C, Zhou Y, Wang D, Miao X, Li Y, Hu B (2020) Neurological manifestations of hospitalized patients with COVID-19 in Wuhan, China. JAMA Neurol 77:1-9. https://doi.org/10.1001/jamaneurol .2020 .1127

Mehta P, McAuley DF, Brown M, Sanchez E, Tattersall RS, Manson JJ, Hlh Across Speciality Collaboration UK (2020) COVID-19: consider cytokine storm syndromes and immunosuppression. Lancet 395:1033-1034. https://doi.org/10.1016/S0140-6736(20)30628-0

Menendez-Pelaez A, Reiter RJ (1993) Distribution of melatonin in mammalian tissues: the relative importance of nuclear versus cytosolic localization. J Pineal Res 15:59-69. https://doi. org/10.1111/j.1600-079x.1993.tb00511.x

Montiel M, Bonilla E, Valero N, Mosquera J, Espina LM, Quiroz Y, Alvarez-Mon M (2015) Melatonin decreases brain apoptosis, oxidative stress, and CD200 expression and increased survival rate in mice infected by Venezuelan equine encephalitis virus. Antivir Chem Chemother 24:99-108. https://doi.org/10.1177/20402 06616660851

Moriguchi T, Harii N, Goto J, Harada D, Sugawara H, Takamino J, Ueno M, Sakata H, Kondo K, Myose N, Nakao A, Takeda M, Haro H, Inoue O, Suzuki-Inoue K, Kubokawa K, Ogihara S, Sasaki T, Kinouchi H, Kojin H, Ito M, Onishi H, Shimizu T, Sasaki Y, Enomoto N, Ishihara H, Furuya S, Yamamoto T, Shimada $S$ (2020) A first case of meningitis/encephalitis associated with SARS-Coronavirus-2. Int J Infect Dis 94:55-58. https://doi. org/10.1016/j.ijid.2020.03.062

Nataf S (2020) An alteration of the dopamine synthetic pathway is possibly involved in the pathophysiology of COVID-19. J Med Virol. https://doi.org/10.1002/jmv.25826

Ng KY, Leong MK, Liang H, Paxinos G (2017) Melatonin receptors: distribution in mammalian brain and their respective putative functions. Brain Struct Funct 222:2921-2939. https://doi. org/10.1007/s00429-017-1439-6

Nickkholgh A, Schneider H, Sobirey M, Venetz WP, Hinz U, Pelzl LH, Gotthardt DN, Cekauskas A, Manikas M, Mikalauskas S, Mikalauskene L, Bruns H, Zorn M, Weigand MA, Büchler MW, Schemmer P (2011) The use of high-dose melatonin in liver resection is safe: first clinical experience. J Pineal Res 50:381388. https://doi.org/10.1111/j.1600-079X.2011.00854.x

Niranjan R, Nath C, Shukla R (2012) Melatonin attenuated mediators of neuroinflammation and alpha-7 nicotinic acetylcholine receptor mRNA expression in lipopolysaccharide (LPS) stimulated rat astrocytoma cells, C6. Free Radic Res 46:1167-1177. https://doi. org/10.3109/10715762.2012.697626

Nishiga M, Wang DW, Han Y, Lewis DB, Wu JC (2020) COVID-19 and cardiovascular disease: from basic mechanisms to clinical perspectives. Nat Rev Cardiol. https://doi.org/10.1038/s4156 9-020-0413-9 
Oakes JM, Fuchs RM, Gardner JD, Lazartigues E, Yue X (2018) Nicotine and the renin-angiotensin system. Am J Physiol Regul Integr Comp Physiol 315:R895-R906. https://doi.org/10.1152/ ajpregu.00099.2018

Otmani S, Demazières A, Staner C, Jacob N, Nir T, Zisapel N, Staner L (2008) Effects of prolonged-release melatonin, zolpidem, and their combination on psychomotor functions, memory recall, and driving skills in healthy middle aged and elderly volunteers. Hum Psychopharmacol 23:693-705. https://doi.org/10.1002/hup.980

Paniz-Mondolfi A, Bryce C, Grimes Z, Gordon RE, Reidy J, Lednicky J, Sordillo EM, Fowkes M (2020) Central nervous system involvement by severe acute respiratory syndrome coronavirus -2 (SARS-CoV-2). J Med Virol 92:699-702. https://doi. org/10.1002/jmv.25915

Parada E, Buendia I, León R, Negredo P, Romero A, Cuadrado A, López MG, Egea J (2014) Neuroprotective effect of melatonin against ischemia is partially mediated by alpha-7 nicotinic receptor modulation and HO-1 overexpression. J Pineal Res 56:204212. https://doi.org/10.1111/jpi.12113

Peschechera E, Veronesi PA (2020) Injectable melatonin: an anti-cancer and anti-viral treatment option. Melatonin Res 3:77-80. https ://doi.org/10.32794/mr11250049

Poyiadji N, Shahin G, Noujaim D, Stone M, Patel S, Griffith B (2020) COVID-19-associated acute hemorrhagic necrotizing encephalopathy: imaging features. Radiology 296:E119-E120. https:// doi.org/10.1148/radiol.2020201187

Pozo D, Garcia-Maurino S, Guerrero JM, Calvo JR (2004) mRNA expression of nuclear receptor RZR/RORalpha, melatonin membrane receptor MT, and hydroxindole-O-methyltransferase in different populations of human immune cells. J Pineal Res 37:48-54. https://doi.org/10.1111/j.1600-079X.2004.00135.x

Qi F, Qian S, Zhang S, Zhang Z (2020) Single cell RNA sequencing of 13 human tissues identify cell types and receptors of human coronaviruses. Biochem Biophys Res Commun 526:135-140. https://doi.org/10.1016/j.bbrc.2020.03.044

Radmanesh F, Rodriguez-Pla A, Pincus MD, Burns JD (2020) Severe cerebral involvement in adult-onset hemophagocytic lymphohistiocytosis. J Clin Neurosci 76:236-237. https://doi.org/10.1016/j. jocn.2020.04.054

Ramos E, Gil-Martín E, Romero A (2020) Chapter three - Melatonin and neurodegeneration: from neurotoxic environment to cell resilience. In: Fishbein JC, Heilman JM (eds) Advances in molecular toxicology, vol 13. Elsevier, Amsterdam, pp 69-108

Ramos E, Patiño P, Reiter RJ, Gil-Martín E, Marco-Contelles J, Parada E, De Los RC, Romero A, Egea J (2017) Ischemic brain injury: new insights on the protective role of melatonin. Free Radic Biol Med 104:32-53. https://doi.org/10.1016/j.freeradbio med.2017.01.005

Rechciński T, Trzos E, Wierzbowska-Drabik K, Krzemińska-Pakuła M, Kurpesa M (2010) Melatonin for nondippers with coronary artery disease: assessment of blood pressure profile and heart rate variability. Hypertens Res 33:56-61. https://doi.org/10.1038/ hr.2009.174

Reiter RJ, Craft CM, Johnson JE Jr, King TS, Richardson BA, Vaughan GM, Vaughan MK (1981) Age-associated reduction in nocturnal pineal melatonin levels in female rats. Endocrinology 109:12951297. https://doi.org/10.1210/endo-109-4-1295

Reiter RJ, Ma Q, Sharma R (2020a) Treatment of ebola and other infectious diseases: melatonin "goes viral". Melatonin Res 3:43-57. https://doi.org/10.32794/mr11250047

Reiter RJ, Ma Q, Sharma R (2020b) Melatonin in mitochondria: mitigating clear and present dangers. Physiology (Bethesda) 35:8695. https://doi.org/10.1152/physiol.00034.2019

Reiter RJ, Tan DX, Kim SJ, Cruz MH (2014) Delivery of pineal melatonin to the brain and SCN: role of canaliculi, cerebrospinal fluid, tanycytes and Virchow-Robin perivascular spaces. Brain
Struct Funct 219:1873-1887. https://doi.org/10.1007/s0042 9-014-0719-7

Rizzo P, Vieceli Dalla Sega F, Fortini F, Marracino L, Rapezzi C, Ferrari R (2020) COVID-19 in the heart and the lungs: could we "Notch" the inflammatory storm? Basic Res Cardiol 115:31. https://doi.org/10.1007/s00395-020-0791-5

Rodriguez C, Mayo JC, Sainz RM, Antolin I, Herrera F, Martin V, Reiter RJ (2004) Regulation of antioxidant enzymes: a significant role for melatonin. J Pineal Res 36:1-9. https://doi.org/10.1046/ j.1600-079x.2003.00092.x

Rosenberg GA (2012) Neurological diseases in relation to the bloodbrain barrier. J Cereb Blood Flow Metab 32:1139-1151. https:// doi.org/10.1038/jcbfm.2011.197

Ruan Q, Yang K, Wang W, Jiang L, Song J (2020) Clinical predictors of mortality due to COVID-19 based on an analysis of data of 150 patients from Wuhan. China Intensive Care Med 46:846848. https://doi.org/10.1007/s00134-020-05991-x

Seabra ML, Bignotto M, Pinto LR Jr, Tufik S (2000) Randomized, double-blind clinical trial, controlled with placebo, of the toxicology of chronic melatonin treatment. J Pineal Res 29:193-200. https://doi.org/10.1034/j.1600-0633.2002.290401.x

Shneider A, Kudriavtsev A, Vakhrusheva A (2020) Can melatonin reduce the severity of COVID-19 pandemic? Int Rev Immunol 39:153-162. https://doi.org/10.1080/08830185.2020.1756284

Shukla M, Chinchalongporn V, Govitrapong P, Reiter RJ (2019) The role of melatonin in targeting cell signaling pathways in neurodegeneration. Ann N Y Acad Sci 1443:75-96. https://doi. org/10.1111/nyas.14005

Silvestri M, Rossi GA (2013) Melatonin: its possible role in the management of viral infections-a brief review. Ital J Pediatr 39:61. https://doi.org/10.1186/1824-7288-39-61

Slominski RM, Reiter RJ, Schlabritz-Loutsevitch N, Ostrom RS, Slominski AT (2012) Melatonin membrane receptors in peripheral tissues: distribution and functions. Mol Cell Endocrinol 351:152-166. https://doi.org/10.1016/j.mce.2012.01.004

Spanish Agency of Medicines and Medical Devices (AEMPS) (2020) EudraCT: 2020-001808-42. Phase II clinical trial, single-blind, randomized, placebo controlled to explore the effectiveness and safety of melatonin i.v. in patients with COVID-19 entered into the ICU (melcovid study). https://www.clinicaltrialsregister.eu/ ctr-search/trial/2020-001808-42/ES/

Stewart LS, Leung LS (2005) Hippocampal melatonin receptors modulate seizure threshold. Epilepsia 46:473-480. https://doi.org/10. 1111/j.0013-9580.2005.30204.x

Su H, Li J, Chen T, Li N, Xiao J, Wang S, Guo X, Yang Y, Bu P (2016) Melatonin attenuates angiotensin II-induced cardiomyocyte hypertrophy through the CyPA/CD147 signaling pathway. Mol Cell Biochem 422:85-95. https://doi.org/10.1007/s1101 0-016-2808-9

Tan D, Hardeland R (2020) Potential utility of melatonin in deadly infectious diseases related to the overreaction of innate immune response and destructive inflammation: focus on COVID- 19. Melatonin Res 3:120-143. https://doi.org/10.32794/mr11250052

Tan DX (2010) Melatonin and brain. Curr Neuropharmacol 8:161-161. https://doi.org/10.2174/157015910792246263

Tan DX, Korkmaz A, Reiter RJ, Manchester LC (2014) Ebola virus disease: potential use of melatonin as a treatment. J Pineal Res 57:381-384. https://doi.org/10.1111/jpi.12186

Tan DX, Reiter RJ (2019) Mitochondria: the birth place, battle ground and the site of melatonin metabolism in cells. Melatonin Res 2:44-66. https://doi.org/10.32794/mr11250011

Tarocco A, Caroccia N, Morciano G, Wieckowski MR, Ancora G, Garani G, Pinton P (2019) Melatonin as a master regulator of cell death and inflammation: molecular mechanisms and clinical implications for newborn care. Cell Death Dis 10:317. https:// doi.org/10.1038/s41419-019-1556-7 
Tiong YL, Ng KY, Koh RY, Ponnudurai G, Chye SM (2019) Melatonin prevents oxidative stress-induced mitochondrial dysfunction and apoptosis in high glucose-treated schwann cells via upregulation of Bcl2, NF-kappaB, mTOR, Wnt signalling pathways. Antioxidants (Basel) 8:198. https://doi.org/10.3390/antiox8070198

Valero N, Nery A, Bonilla E, Espina LM, Chacin-Bonilla L, Añez F, Maldonado M, Meleán E (2009) Antagonistic effect of luzindole in mice treated with melatonin during the infection with the venezuelan equine encephalomyelitis virus. Neurochem Res 34:268-273. https://doi.org/10.1007/s11064-008-9766-x

Vriend J, Reiter RJ (2014) Melatonin and ubiquitin: what's the connection? Cell Mol Life Sci 71:3409-3418. https://doi.org/10.1007/ s00018-014-1659-3

Wan Y, Shang J, Graham R, Baric RS, Li F (2020) Receptor recognition by the novel coronavirus from wuhan: an analysis based on decade-long structural studies of SARS Coronavirus. J Virol 94:e00127-e220. https://doi.org/10.1128/JVI.00127-20

Wang D, Hu B, Hu C, Zhu F, Liu X, Zhang J, Wang B, Xiang H, Cheng Z, Xiong Y, Zhao Y, Li Y, Wang X, Peng Z (2020a) Clinical characteristics of 138 hospitalized patients with 2019 novel coronavirus-infected pneumonia in Wuhan, China. JAMA 323:1061-1069. https://doi.org/10.1001/jama.2020.1585

Wang K, Chen W, Zhou Y et al (2020b) SARS-CoV-2 invades host cells via a novel route: CD147-spike protein. bioRxiv. https:// doi.org/10.1101/2020.03.14.988345

Wu J, Cao S, Li Y, Yue H, Li C, Xia M, Liu F (2020) Insight from a noticeable difference between two families infected with COVID-19. Res Sq. https://doi.org/10.21203/rs.3.rs-22850/v1

Xia H, Lazartigues E (2010) Angiotensin-converting enzyme 2: central regulator for cardiovascular function. Curr Hypertens Rep 12:170-175. https://doi.org/10.1007/s11906-010-0105-7

Xiang PPP, Xu XM, Gao LL (2020) First case of 2019 novel coronavirus disease with encephalitis. ChinaXivT 202003:00015

Xiao F, Tang M, Zheng X, Liu Y, Li X, Shan H (2020) Evidence for gastrointestinal infection of SARS-CoV-2. Gastroenterology 158:1831-1833. https://doi.org/10.1053/j.gastro.2020.02.055

Xu H, Zhong L, Deng J, Peng J, Dan H, Zeng X, Li T, Chen Q (2020a) High expression of ACE2 receptor of 2019-nCoV on the epithelial cells of oral mucosa. Int J Oral Sci 12:8. https://doi. org/10.1038/s41368-020-0074-X

Xu J, Zhong S, Liu J, Li L, Li Y, Wu X, Li Z, Deng P, Zhang J, Zhong N, Ding Y, Jiang Y (2005) Detection of severe acute respiratory syndrome coronavirus in the brain: potential role of the chemokine mig in pathogenesis. Clin Infect Dis 41:1089-1096. https://doi.org/10.1086/444461

Xu X, Chen P, Wang J, Feng J, Zhou H, Li X, Zhong W, Hao P (2020b) Evolution of the novel coronavirus from the ongoing Wuhan outbreak and modeling of its spike protein for risk of human transmission. Sci China Life Sci 63:457-460. https://doi.org/10.1007/ s11427-020-1637-5

Xu X, Wang G, Ai L, Shi J, Zhang J, Chen YX (2018) Melatonin suppresses TLR9-triggered proinflammatory cytokine production in macrophages by inhibiting ERK1/2 and AKT activation. Sci Rep 8:15579. https://doi.org/10.1038/s41598-018-34011-8

Ye M, Ren Y, Lv T (2020) Encephalitis as a clinical manifestation of COVID-19. Brain Behav Immun 88:945-946. https://doi. org/10.1016/j.bbi.2020.04.017

Zetner D, Andersen LP, Rosenberg J (2016) Pharmacokinetics of alternative administration routes of melatonin: a systematic review. Drug Res (Stuttg) 66:169-173. https://doi. org/10.1055/s-0035-1565083

Zhai P, Ding Y, Li Y (2020) The impact of COVID-19 on ischemic stroke. Diagn Pathol 15:78. https://doi.org/10.1186/s13000-02000994-0

Zhang R, Wang X, Ni L, Di X, Ma B, Niu S, Liu C, Reiter RJ (2020) COVID-19: melatonin as a potential adjuvant treatment. Life Sci 250:117583. https://doi.org/10.1016/j.lfs.2020.117583

Zhao H, Shen D, Zhou H, Liu J, Chen S (2020) Guillain-Barre syndrome associated with SARS-CoV-2 infection: causality or coincidence? Lancet Neurol 19:383-384. https://doi.org/10.1016/ S1474-4422(20)30109-5

Zhou P, Yang XL, Wang XG et al (2020a) A pneumonia outbreak associated with a new coronavirus of probable bat origin. Nature 579:270-273. https://doi.org/10.1038/s41586-020-2012-7

Zhou Y, Hou Y, Shen J, Huang Y, Martin W, Cheng F (2020b) Network-based drug repurposing for novel coronavirus 2019-nCoV/ SARS-CoV-2. Cell Discov 6:14. https://doi.org/10.1038/s4142 1-020-0153-3

Zou X, Chen K, Zou J, Han P, Hao J, Han Z (2020) Single-cell RNAseq data analysis on the receptor ACE2 expression reveals the potential risk of different human organs vulnerable to 2019nCoV infection. Front Med 14:185-192. https://doi.org/10.1007/ s11684-020-0754-0

Publisher's Note Springer Nature remains neutral with regard to jurisdictional claims in published maps and institutional affiliations. 